\title{
EXCLUSÃO E POLÍTICAS PÚBLICAS: dilemas teóricos e alternativas políticas
}

\author{
Alba Zaluar
}

Tornou-se moeda corrente hoje no Brasil falar de exclusão social para abordar uma série de temas e de problemas nem sempre claramente diferenciados, nem sempre rigorosamente definidos. O conceito, mais conhecido e utilizado na França, recoloca algumas das questões abordadas no tema da underclass, sem os pressupostos teóricos e as conseqüências deste último, de inspiração e uso estadunidense. Este, desenvolvido mais recentemente nas discussões a respeito das cidades globais ou duais (Sassen, 1991; Castels e Mollenkopf, 1992), tem a classe como referência principal na medida em que reflete sobre o que falta, por comparação com a classe operária, aos pobres que não têm emprego regular, vivem em guetos, fazem parte de famílias desagregadas, estão submetidos à dependência de drogas ilícitas e têm vizinhança com altas taxas de criminalidade. Por isso, o conceito guarda proximidades teóricas importantes com as teorias desenvolvidas na América Latina a respeito do mercado informal e da marginalidade, vinculando, sobretudo, o econômico ao social. A exclusão, por sua vez, vincula o econômico ao político e ao social mas tem por referências, além da cidadania e da inserção na sociedade nacional, as fronteiras (não explicitadas) entre os grupos e a lógica classificatória, referências estas nem sempre claras nos que usam o conceito de forma abusiva entre nós.

Para esclarecermos as dúvidas e equívocos que perseguem aquele que pretende usar o conceito de exclusão com um mínimo de rigor, temos que enfrentar e diferenciar duas ordens de problemas: o problema teórico e o problema prático-político, muitas vezes confundidos na retórica que vulgarizou o uso do termo.

\section{Os problemas teóricos}

O conceito ou o termo exclusão vem, de fato, de toda uma tradição nos estudos de sistemas simbólicos que dominaram o pensamento social, especialmente aquele mais influenciado pela Antropologia Estrutural. Nesta, 
como se sabe, privilegia-se na análise não a política dos significados no discurso, nem a relação do discurso com os seus referentes, mas as propriedades da cadeia de significantes; ou seja, importa pouco ou nada a relação do nome com a realidade que encobre, e muito mais as relações entre os nomes no sistema que eles formam. Esta cadeia de significantes monta-se logicamente pela inclusão/exclusão de categorias que recortam o real e permitem a sua comunicação. É a lógica classificatória ou a lógica binária (o sim/não dos computadores ou da inteligência artificial) que é utilizada, desse modo, para marcar diferenças, possibilitadas pelos sinais que as carregam — os sinais diacríticos —, que resultam em conjuntos de sons ou letras denominados significantes. Essa lógica corresponde àquilo que os franceses chamamstructurelle, ou seja, as relações formais entre os elementos de um sistema simbólico, para diferenciar dostructurale, associado ao social, ao moral, às relações entre pessoas, também formando um sistema. Tal teoria desenvolvida na Antropologia revelou-se boa teoria para pensar as identidades contrastivas nas fronteiras entre grupos que se tocam ou se enfrentam e que se representam simbolicamente como diferenciados. Mas é teoria problemática para pensar todos os tipos de comunidades, mais ou menos abrangentes, em que os laços sociais ou morais, a reciprocidade, a solidariedade, a mutualidade, a autoridade, e não apenas a lógica classificatória ou o jogo exclusivista do poder e da diferenciação, entram nas apostas complexas com que múltiplos atores movimentam o campo social e o político.

Do ponto de vista da teoria dos sistemas simbólicos, podemos afirmar que qualquer sistema classificatório ou qualquer comunidade, como identidade que se diferencia de outras, cria exclusão: grupos religiosos, étnicos, raciais, familiares, tribais, localidades, nações etc. Mas tais grupos criam a exclusão por processos diferentes e por critérios distintos, tendo maior ou menor flexibilidade, fronteiras mais ou menos fluidas, além de laços ou relações entre seus membros de natureza bastante diversa. Esta é a primeira dificuldade de se focalizar apenas o sim/ não da inclusão/ exclusão. Qualquer sistema de classificação pensado apenas em termos da lógica binária, na medida em que precisa de fronteiras nítidas a separar suas partes - e isso não se reduz aos sistemas polarizados entre duas categorias apenas —, produz a exclusão, que vem a ser, portanto, um traço constitutivo da classificação na qual se baseia o conceito estrutural de identidade social. Mesmo os sistemas de categorias múltiplas, se as fronteiras entre elas são rigidamente precisadas, criam exclusões e conflitos potenciais. É preciso, pois, entender as zonas sombreadas entre as comunidades ou grupos sociais, os processos de integração ou expulsão de cada um deles e, por fim, as relações internas entre os incluídos, assim como as relações entre a comunidade ou grupo dos incluídos e os outros grupos de igual ou de outra natureza. Algumas dessas comunidades são mais fluidas, mais abertas ou mais abrangentes do que outras. Umas referem-se aos direitos e deveres adquiridos por se nascer num território; outras, a laços de consangüinidade ou de ancestralidade; outras, ainda, a características morais, intelectuais ou psicológicas de seus membros que são negadas às outras pessoas delas excluídas. Nações podem ser construídas por diferentes combinações desses critérios, dando maior ou menor importância a cada um deles — como, por exemplo, a ancestralidade e a raça comum, discutidos no conceito de etnonacionalismo de Tambiah (1997) —, o que vai tornálas mais ou menos excludentes no que se refere à capacidade de aceitar os forasteiros ou imigrantes. Umas comunidades podem ter processos de admissão, conversão ou inclusão bastante facilitados, e outras, critérios mais exigentes. A maioria dos países europeus tem grande parte de seu problema da exclusão devida à não aceitação dos imigrantes recentes como membros da sociedade nacional, gerando uma nova forma de racismo cultural. De qualquer modo, optar pela inclusão é optar por um patamar comum de identidade e pertencimento social, sobrepujando as diferenças.

Com relação a isso, o Brasil é um dos países mais flexíveis e menos excludentes do mundo. A falta de homogeneidade étnica e racial faz dele um país multicultural por vocação, apesar das discriminações "sutis" ocorrerem, e um país mais aberto às diversas identidades étnicas existentes no 
mundo. Ao mesmo tempo, sua vocação para a defesa do hibridismo ameniza as diferenças e cria um núcleo racial e cultural comum, como resultado da própria mistura. Também por isso o Brasil não é um país em que as formas violentamente excludentes do racismo biológico do passado ou do racismo cultural do presente sejam tão marcantes. É, na verdade, um país que rejeita teoricamente o racismo, embora na prática apresente sinais de discriminação dos negros e dos mestiços provenientes da mistura entre os vários negros e "brancos" que aqui aportaram e os indígenas que aqui já estavam. Entretanto, o mesmo não se pode dizer sobre as exclusões advindas da pobreza. Quando as discriminações raciais combinam-se com as discriminações contra o pobre, tem-se as mais claras situações de exclusão em diversos setores, por variados processos.

O outro problema teórico nessa abordagem é que a existência de comunidades ou grupos mais ou menos fechados não cria necessariamente uma situação de injustiça. Pertencer ou não a uma família, a um grupo religioso, a um grupo étnico, a uma tribo não significa viver forçosamente uma situação de injustiça social, de falta material ou de carência relativamente aos outros grupos. Quando, então, exclusão e injustiça se sobrepõem? Neste caso, excluídos e membros da underclass seriam os mesmos? Apesar dos pontos de convergência e superposição, ainda assim o debate sobre a exclusão tem um foco diverso daquele estabelecido pelos que pensam a injustiça sob a ótica da underclass.

Os autores da linha teórica francesa dedicados à questão social dos dias de hoje concordam em que, para se pensar sobre a injustiça social, temos de considerar não mais os pequenos grupos, mas as sociedades nacionais na sua relação com Estados nacionais. A exclusão como manifestação de injustiça (distributiva) se revela quando pessoas são sistematicamente excluídas dos serviços, benesses e garantias oferecidos ou assegurados pelo Estado, pensados, em geral, como direitos de cidadania. Outros acentuam que, mesmo assim, teríamos quadros, níveis e graus de exclusão bastante diferenciados. Seria preciso, pois, conhecer os processos que levam à exclusão e o conteúdo particular das diversas exclusões para se ter um entendimento mais verdadeiro e menos retórico da exclusão. Por exemplo, as trajetórias e as situações vividas por meninos de rua, jovens usuários de drogas, favelados, trabalhadores desempregados ou biscateiros, homossexuais, umbandistas, negros e mestiços são muito diferentes entre si. Por fim, outros mais discutem a justiça como conceito de maior abrangência, que obriga a pensar não apenas as relações entre a sociedade e o Estado, mas também as relações interpessoais, os compromissos variados assumidos e as possíveis participações de e entre diversos setores da sociedade no espaço público, que não se confunde com o Estado, nem com o Mercado. Isso nos leva à segunda ordem de problemas.

\section{Os problemas prático-políticos}

$\mathrm{Na}$ sua dimensão política, o termo exclusão refere-se atualmente, no debate sobre a crise do Welfare State, à exclusão ou integração na sociedade nacional. É assim que a maior parte dos autores usa o termo. Pierre Rosanvallon (1995), por exemplo, é um universalista, e não um comunitarista, na sua perspectiva sobre a exclusão por pensar a cidadania individual na dimensão da participação política e civil na sociedade nacional. Ele pensa os direitos reais e não os escritos nas declarações dos direitos universais do homem, nas constituições nacionais e demais códigos de leis, que, por nem sempre serem implementados, revelam o seu caráter meramente formal e não real. Dessa perspectiva, a participação política e civil implica responsabilidades e deveres concretos, e não apenas direitos vagamente expressos em lei. Assim, a pessoa não é sujeito de direitos assegurados pela letra da lei, mas objeto de atendimento e proteção, ao mesmo tempo em que é sujeito disponível para cumprir várias funções perante a sociedade nacional, ou seja, prestar contrapartidas pelos serviços recebidos do Estado. É nesse sentido que se fala em "refazer a nação" com novas solidariedades, novas utilidades sociais, novas identidades. Dessa maneira, Rosanvallon tenta articular os chamados direitos sociais ou 
coletivos, que se estendem a uma categoria de pessoas consideradas prejudicadas de alguma forma, com os direitos e deveres individuais. Não se trata apenas do direito coletivo a uma parcela da riqueza criada nacionalmente, mas também dos deveres individuais ou das obrigações morais de cada um com todos os outros que compõem a nação.

Basicamente, esse autor posta-se contra a cidadania passiva, que se caracterizou por afirmar e assegurar os direitos do trabalho, desenvolvendo uma política de mera proteção, para garantir o direito à vida. Como se sabe, esse sistema gerou uma tensão e, finalmente, uma crise entre a autonomia assim adquirida por cada um e a solidariedade geral, visto que a vida nos nichos da pobreza, por causa do excessivo número de protegidos, permitiu o "vampirismo" da sociedade nacional e passou a minar esta mesma solidariedade. Na cidadania ativa, não se trata apenas do direito à vida, mas do direito à vida em sociedade, ou seja, à participação civil e política que implica, em primeiro lugar, contrapartidas da parte de quem é atendido. Do mesmo modo, não se trata apenas do direito do trabalho, mas do direito ao trabalho, sendo para tanto necessário superar a interpretação contratualista da solidariedade. Nesta concepção contratualista, os direitos sociais são apenas do trabalhador em risco, ou seja, a assistência é dada apenas aos que não podem trabalhar (estendida às vezes aos "caronas", que acabam por se acostumar com o benefício e deixam de querer trabalhar no mercado formal de trabalho), garantida pela contribuição dos que podem e querem trabalhar. A cotização entre os trabalhadores é o fundamento da solidariedade e a redistribuição é conseqüência desse mérito pelo trabalho. $\mathrm{Na}$ atual fase de globalização da economia, com as transformações tecnológicas alterando profundamente o processo de trabalho, o desemprego em massa resultante e o crescimento do mercado informal junto às formas desregulamentadas de vinculação capital-trabalho mudaram tudo isso. Conseqüentemente, a crise financeira do Estado Providência reacendeu a preocupação com os que evitam o trabalho por terem desenvolvido o "vício" da dependência, tornando-se parasitas dos demais. Assim, a discussão sobre os "pobres merecedores" ou os aspectos morais da questão retornaram à cena, desta vez acenando com soluções mais democráticas.

A proposta é, então, que o Estado Passivo Providência seja substituído pelo Estado Ativo Providência. Não haveria mais assistidos a socorrer, mas pessoas com diferentes utilidades sociais, cuja capacidade deveria ser sempre aproveitada. Nele também haveria a socialização radical dos bens e das responsabilidades. Uma nova concepção de solidariedade é mobilizada na ideologia desse Estado: não é nem a caridade privada, nem o bem-estar advindo dos direitos sociais, nem a mutualidade do solidarismo do século XIX. Refazer a nação, lema dessa ideologia, significa fomentar a solidariedade advinda do pertencimento a uma mesma comunidade nacional, na qual a seguridade é nacional - o novo sentido do social, visto que a questão social é nacional —, solidariedade que se traduz em direitoe dever à integração. Nesse "Estado Cívico Providência", como o chamou Rosanvallon, a civilidade construída por um processo educativo generalizado, ao mesmo tempo escolar e extra-escolar, torna-se uma alternativa para as tentativas, muitas frustradas, de remediar a sociabilidade insociável de que fala Kant. Nele, idealmente, as políticas públicas deveriam se ocupar de prevenir a exclusão mais do que de reinserir os excluídos; de criar uma sociabilidade positiva mais do que de remediar a negativa, embora no quadro de crise atual o oposto tenha que ocorrer na política de reinserção. Os atores desse projeto seriam diferentes: não mais os sindicatos e o Estado redistribuidor, mas uma série de associações de diversos tipos, junto às quais o Estado ainda seria o principal ator do social, criando nova legitimidade para a sua intervenção.

Nas atuais políticas de reinserção, em que se remedia o que não se preveniu a tempo, o programa de renda mínima francês - o RMI — incorpora algumas das reflexões sobre o Estado Ativo Providência e propõe a institucionalização de uma dívida social, porém com uma contrapartida: o compromisso pessoal do beneficiário com a sociedade nacional. Trocando em miúdos, isso significa o engajamento deste em diversas atividades, seja ações em que ele investe na sua própria formação, seja ações de 
interesse geral em diversas associações, seja o simples esforço de readaptação, no caso dos usuários de drogas, dos condenados por crimes de menor gravidade etc. A própria concepção de trabalho tem que ser modificada, recuperando as propostas de Keynes no início do século: não a idéia do trabalho produtivo economicamente, que resulta num produto que gera mais-valia, mas a idéia do trabalho socialmente útil, que pode ser desde vender suco de laranja na rua ou ajudar a limpar um bairro pobre, a reflorestar áreas em iniciativas estatais para diminuir o desemprego, até atender doentes, idosos, crianças ou pessoas em diversas situações de risco sem ser um profissional da área. Essa desprofissionalização das ações de solidariedade é acompanhada pela descentralização das decisões sobre os que devem receber e continuar recebendo os diversos tipos de auxílio. Essa descentralização, contudo, não se limita a uma transferência do poder federal para o municipal, mas supõe a criação de um sistema reticular em que cidadãos comuns, trabalhadores representantes de suas categorias profissionais e seus bairros, associações patronais, religiosas e outras participem do mesmo fórum de discussão sobre os critérios e sobre as pessoas a serem incluídas no plano (Affichard, 1995).

Por causa dos problemas teóricos abordados acima, outro autor - Robert Castel (1995) — prefere falar de desafiliação e não de exclusão e propõe diferentes políticas para resolver a questão. Essa simples troca de nome é importante na medida em que afiliação remete a um processo, que envolve sujeitos ativos, e não à lógica binária da classificação. Robert Castel trabalha também com as possíveis e necessárias escolhas dentro de sociedades nacionais que, mesmo étnica e racialmente homogêneas anteriormente, hoje apresentam um quadro de heterogeneidade marcado pelo racismo explícito. Chama a atenção para o fato de que as políticas de integração a uma sociedade nacional não devem perder de vista essas situações diferenciadas por religião, identidade étnica, raça e gênero, retomando o tema do pluralismo e do multiculturalismo. Assim mesmo, como todos os outros, o autor repete o mote da integração na sociedade nacional daqueles que são os mais atomizados, os mais inúteis, os mais indiferentemente tratados por todos. É isso que o leva a falar de "individualismo negativo", o individualismo dos que ficaram ilhados no esgarçamento do tecido social, isolados, atomizados, sem o ideário e os valores partilhados socialmente, o individualismo dos que, pelo narcisismo, buscaram as ilusões de uma independência individual absoluta e encontraram o vazio.

Para Castel, o grande desafio das sociedades nacionais européias seria abalar o exílio — mais ou menos forçado — da cidadania e da sociedade nacional vivido hoje por uma parcela da população e que, tendencialmente, poderia vir a afetar todos. Seu entendimento da exclusão é o mais próximo do conceito de underclass, empregado para pensar a situação de moradia, moralidade e trabalho dos membros de minorias étnicas nos Estados Unidos (Jenks, 1992; Katz, 1989; Danzinger e Weinberg, 1986). Como, para ele, o aspecto principal da exclusão é o fim da condição salarial, que significa emprego estável, família constituída, grupo religioso e de vizinhança homogêneos, o resultado é a vida no aleatório, no imprevisível, na incerteza do amanhã que o trabalho temporário, o biscate, ou seja, a alternância dos períodos de atividade e de inatividade impõem hoje aos que se encontram na idade de trabalhar. Estes são, por conseguinte, sujeitos por defeito, porque acabam excluídos de todos os coletivos protetores: família, grupo de vizinhança, grupo religioso, empresa, sindicato etc. Desse modo, o nacional dever estar combinado ao local ou ao particular na análise da desafiliação para que se encontre seus antídotos próprios. Aqui também Castel aproxima-se mais da discussão estadunidense da justiça que segue a linha comunitarista, procurando a articulação desta perspectiva com a universalista, concebida na linha societária.

Por isso mesmo, Castel assinala que a exclusão do jovem drogado não é a mesma do desempregado estrutural, o que exige políticas públicas diferentes para reintegrá-los. De um modo geral, suas críticas dirigem-se mais às políticas do bem-estar, por serem políticas pos facto, para remediar uma situação e não para preveni-la. No cômputo final, ele valoriza muito mais as políticas de emprego mais enérgicas, que revertessem as crescentes dificuldades advindas com o 
fim da "sociedade do trabalho". Essas políticas seriam econômicas e tentariam modificar a estrutura da produção, com ampla intervenção do Estado.

Daí os seus reparos à lei sobre o RMI, que ele considera promover a inserção com ambigüidades. A "renda mínima de integração" é um imperativo nacional, pensada como ajuda temporária aos que tombaram durante a crise. Entretanto, o que foi imaginado como transitório acabou se instalando como permanente entre os desempregados, que passaram a viver consecutivamente do auxílio desemprego, criando hábitos de ócio e viciando o cidadão. Desse modo, Castel também se coloca contra o neofilantropismo e concorda que o inserido deveria contribuir com contrapartidas pela sua inserção. Mas, ao contrário de Rosanvallon, propõe que a integração política e civil com responsabilidade deveria ser acompanhada de possibilidades reais de emprego estável.

Nessa linha de raciocínio, o Estado moderno deveria redefinir suas funções e reencontrar sua legitimidade perdida. O problema é que, segundo ele, as novas formas de inserção que não apenas o trabalho estável, as novas formas de identidade, de solidariedade e de utilidade social prejudicam uns mais do que outros. O direito aotrabalho, e não do trabalho, não se põe da mesma forma para todos. Ele até admite que possamos estar no fim da sociedade salarial, em que o trabalho é o vetor principal da integração, mas adverte que devemos prestar atenção nos que permanecem de fora nesse longo processo de construção da nova cidadania que está longe de ser concluído. Hoje, os desempregados ou os assistidos pelo RMI ainda pensam que o emprego é a maior expressão da dignidade e da cidadania. O que fazer com os mais prejudicados pelo fim do vínculo salarial, ou seja, os mais fracos e os mais despossuídos, os que ficam a esperar que novas formas de identidade e de cidadania se imponham? Medidas políticas urgentes e de restruturação da economia global ainda estão no horizonte do debate em curso, que não se resolve com a fórmula mágica da descentralização para integrar os mais pobres.
$\mathrm{Na}$ sociedade atual, em que as classes sociais, tais como foram reconhecidas e analisadas no século XIX e na primeira metade deste, não são mais as únicas divisões relevantes, segmentarizações múltiplas criaram outras exclusões e novos sujeitos de direito nas lutas que se seguiram. A institucionalização de qualquer vínculo entre o homem e a mulher fez-se no Brasil, por exemplo, ainda excluindo os homossexuais de auferirem as mesmas garantias e direitos contratuais na formação do casal. Mas o próprio conceito de direitos humanos, que se aplicava àquelas categorias que não eram contempladas com os direitos civis, passa a ser cada vez menos invocado à medida que as leis nacionais incorporam as reivindicações desses segmentos. Muitas das lutas levadas à frente como sendo de direitos humanos, especialmente no que se refere à violência institucional contra os pobres, na verdade são lutas para tornar seus direitos civis reais, e não meramente formais, pois já estão na letra da lei. Os pobres no Brasil não são considerados estrangeiros, como os árabes e seus descendentes na França, assim como os negros africanos e antilhanos na Inglaterra e na França.

Vivemos então, hoje, entre dois perigos. A tendência a pensar os direitos específicos em detrimento dos gerais, ou as identidades locais ignorando as nacionais e até mesmo as supranacionais e internacionais, criou o perigo de acentuar demasiadamente a autonomia das comunidades específicas e das localidades, o que acabaria por esfacelar a nação, com sérios problemas para a integração dos pobres, já que a questão social, segundo o entendimento dos que a pensaram, é uma questão basicamente nacional. Um dos perigos da descentralização nas políticas públicas seria justamente esse de reforçar as solidariedades e identidades locais, o que acabaria por deixar uma legião de pobres migrantes de fora, rejeitados pelos municípios mais ricos, como já acontece em vários estados do Sul, no interior de São Paulo e em alguns municípios de Minas Gerais. Isso representaria um retrocesso à política social inglesa dos séculos XVII e XVIII, que se caracterizou pela imobilização dos pobres nos seus municípios de origem (Himmelfarb, 1984) e por enormes diferenças intermunicipais. 
O outro perigo reside na idéia de nação como a pátria que exige todos os sacrifícios de seus filhos, inclusive a perda de suas identidades específicas, com a qual acabaríamos por eliminar completamente as diversidades em benefício exclusivo da identidade nacional. A questão é, pois, como refazer a nação. Nesse refazer, a articulação entre os níveis reconhecidos de sociabilidade e solidariedade tem que ser reconstituída. O cosmopolitismo significa não o abandono da sociabilidade interpessoal ou da reciprocidade como princípio dos laços interpessoais, mas uma extensão desses laços para além dos mundos restritos da família, matriz de outros grupos primários. Assim, os limites da vizinhança, ou mesmo do associativismo característico da modernidade, bem como os dos sindicatos, grupos profissionais restritos, partidos políticos e grupos religiosos fechados, têm que ser ultrapassados para incluir e integrar, num nível mais geral, camadas da população em circuitos mais amplos de solidariedade.

Nunca é demais lembrar que a opção crescente pelo conceito de exclusão, de fabricação francesa, revela o objetivo final da integração, do pertencimento a uma unidade maior que é a própria idéia de nação. Isto, por sua vez, repõe a nova questão social: não se trata apenas do contrato civil entre duas pessoas ou organizações, nem do contrato político patrocinado e mediado pelo Estado, que controla a soberania sobre o território e a submissão de todos à lei. $\mathrm{Na}$ nova questão social, trata-se do compromisso de cada um com os demais, de todas as pessoas pertencentes à nação entre si, em circuitos de variadas trocas (Ricoeur, 1990). Ao mesmo tempo, relativiza-se o critério universalista da justiça, baseado na idéia da justiça igual para todos, abrindo-se lugar para critérios locais, situacionais e diversificados, desenvolvidos nos variados circuitos de distribuição e troca nos quais o Estado não é mais o único mediador.

A discussão sobre a reciprocidade no mundo moderno coloca-se, pois, como um tema de extrema atualidade, a julgar pelos inúmeros trabalhos publicados pela associação M.A.U.S.S. (Mouvement Anti-Utilitariste des Scientistes Sociaux) e outros mais que pretendem rediscutir o mercado, o interesse, a impessoalidade e a regra burocrática como os ícones da modernidade no pensamento sociológico, advindos do utilitarismo, para reintroduzir o laço interpessoal, o desinteresse no ganho, a racionalidade comunicativa, a reciprocidade de amplos circuitos como saídas aos impasses criados pelo neoliberalismo.

\section{A reciprocidade na modernidade}

Uma das correntes mais influentes da Antropologia caracterizou o social como a esfera da reciprocidade, dos laços morais e da comunicação interpessoal, sem deixar de ver as ambivalências e conflitos de todos esses termos. $\mathrm{Na}$ construção da idéia de ordem social, de organização, de sociabilidade ou de socialidade positiva, tais conceitos foram utilizados inicialmente, muito criticados depois e recuperados mais tarde. Hoje, no término do século, o esgarçamento do tecido social, a violência urbana, a fragmentação que atinge todas as formas de organização celular e a perda de ímpeto dos movimentos sociais, além dos novos desafios colocados pela teoria econômica neoliberal, que permanece centrada no indivíduo e no interesse, têm levado numerosos cientistas sociais a recuperar os termos do debate no início do século.

Não por acaso, a primeira teoria da reciprocidade surgiu nas primeiras décadas do século XX, numa época prékeynesiana, quando imperavam as teorias liberais do mercado - anteriormente, portanto, às tentativas de combater a corrosão na sociedade provocada pelo mercado sem limites institucionais e morais. Na teoria de Marcel Mauss, os três momentos da reciprocidade — dar, receber e retribuir — formariam uma unidade possibilitada pelo caráter total do dom. O bem doado, carregado de força vital, da energia que obrigaria à retribuição, faria a mágica de reunir as pessoas, de criar laços sociais entre elas. O bem seria, pois, o mediador nessas relações interpessoais e intergrupais. Mas circularia no circuito restrito das relações interpessoais, constituindo a comunidade das relações primárias. 
Mauss, no entanto, não tinha uma concepção ingênua do dom, apontando para seus aspectos negativos e ambivalentes. A ambivalência do dom estaria presente nas conotações sugeridas pela sua raiz grega dosis, associada a dose, a veneno, que não chegaria a matar quando oferecido em pequenas doses, à altura da capacidade de devolvê-lo, mas que afrontaria os que o recebessem em tais doses que não tivessem condições de retribuí-lo. De fato, nos inúmeros exemplos etnográficos de que se vale para tecer sua teoria, Mauss descreve como o presente sem possibilidade de retribuição humilha o recebedor, chegando a ser perigoso e falso como no "presente de grego", expressão de uso corrente em muitos locais e em várias línguas. O dom é também um recurso do poder, usado em rituais de exibição de status, garantindo uma posição de prestígio e poder ao doador; ou seja, o dom não é puro desinteresse nem absoluta generosidade, mas seu caráter interessado é muito mais simbólico do que material. A reciprocidade também se mantém no fio doagon, que impulsiona os seres humanos à competição, à rivalidade e à vingança quando são lesados ou ofendidos (Boilleau, 1995).

O dom é ao mesmo tempo interesse e desinteresse, generosidade e cálculo estratégico ou instrumental, expressos no plano simbólico e não material, que se conservam em tensão permanente, especialmente nas relações entre desiguais. Por isso mesmo, diz Mauss, uma de suas perversões é a esmola da caridade cristã, a filantropia humilhante. Nós poderíamos acrescentar: o clientelismo na sua articulação com o político, que instrumentalizou a lealdade pessoal para fins eleitorais na Primeira República; o neoclientelismo que privatiza verbas e serviços públicos hoje com o mesmo fim; a lealdade associada ao terror que caracteriza as relações pessoais dentro das máfias, o que elimina o ato livre do que aposta no dom.

A reciprocidade e o dom em circuitos simétricos e assimétricos da troca, porque são a base ou o cimento de qualquer sociabilidade, não se restringiram, como sugeriu o próprio Marcel Mauss, às sociedades ditas tribais ou primitivas. Os circuitos específicos das sociedades modernas e contemporâneas, nas suas conseqüências econômicas e políticas, assim como nos seus aspectos positivos e negativos, têm sido cada vez mais objeto de análise de inúmeros autores, em diferentes campos sociais: no cuidado médico, na previdência social, na doação de sangue e de órgãos, na política fiscal do Estado, nos diversos movimentos sociais, mas também nos circuitos de vingança privada e no próprio sistema penal moderno, que não perdeu inteiramente o seu caráter vingativo. No social sempre houve o entrelaçamento entre a necessidade (ou o interesse) e o dom, a inveja e a solidariedade, apesar das afirmações às vezes exageradamente otimistas dos críticos do interesse próprio como o cimento da sociedade. Falar apenas de reciprocidade, portanto, não basta. É preciso saber de que reciprocidade se trata, do seu contexto social, dos seus limites comunitários, dos seus circuitos, de quem, enfim, dela faria parte e com base em que critérios ou razões.

Assim, o debate atual sobre os conceitos de reciprocidade, desinteresse e interesse é crucial para a reaproximação do econômico, do político e do social, tão dissociados nestes anos 90 neoliberais, bem como para o entendimento das relações envolvidas no que se convencionou chamar a nova questão social. Ao mesmo tempo, o campo da discussão sobre justiça ampliou-se, abarcando hoje vários ramos, segundo princípios diferentes: o dos direitos legais (Justiça como instituição) e o das necessidades materiais (justiça social). Ambos, porém, baseiam-se na discussão retomada recentemente acerca da reciprocidade e da solidariedade entre os homens em geral (direitos e deveres universais, abstratos) ou entre pessoas concretas pertencentes a comunidades específicas (direitos e deveres específicos e concretos).

Essa discussão tem sido impulsionada pelo Movimento Anti-Utilitarista dos Cientistas Sociais na França, o qual tem procurado sempre retraçar os caminhos da reconstrução do tecido social ou daquilo que Francis Farrugia (1993) chamou de laço social. Segundo os autores desse movimento, o laço social ou as novas formas de reciprocidade embasariam as novas convivências ("o querer viver juntos", segundo a concepção de Hannah Arendt); constituiriam o novo contrato da civilidade, que não é mais 
o contrato civil nem o contrato político com o Estado, mas um contrato de cada um com todos os que fazem parte da comunidade nacional; justificariam as novas formas de legitimidade que ressaltam o caráter racional do Estado (segundo Habermas e Ricoeur), no qual a violência exercida deve ser limitada, controlada e justificada; criariam as novas formas de solidariedade nas quais o Estado seria também o catalisador de inúmeros circuitos de reciprocidade e solidariedade que necessitam definição. Aqui, trata-se da reaproximação entre o social e o político, ou da repolitização dos laços sociais, ligando-os aos direitos sociais e à cidadania. Ou seja, trata-se da superposição entre Estado Providência e Estado Nação.

Um dos autores neste debate, o canadense Godbout (1992), procura justamente construir teoricamente o espaço da reciprocidade moderna, que se distinguiria do mercado, do Estado e da reciprocidade tradicional que circunscreve apenas as comunidades domésticas. Do mercado, a reciprocidade diferenciar-se-ia porquanto ela cria, ao deixar o receptor na obrigação de retribuir ao doador o bem doado, uma relação, um laço, um vínculo entre os parceiros da troca que não tem tempo demarcado, podendo estenderse num futuro remoto, quanto mais proximidade social houver entre os parceiros. Nela também os bens trocados têm sobretudo valor simbólico, valor de uso marcado pelas relações sociais nas quais deve ser exibido, consumido ou destruído. No mercado, a troca baseada no princípio da equivalência ou medida pelo dinheiro (o equivalente geral) extinguiria a relação no próprio ato de trocar. Nele, os bens têm valor de troca mensurável quantitativamente. No Estado, o princípio presente na movimentação de bens e serviços, pelo menos teoricamente, é o da eqüidade e da justiça num sistema baseado em relações impessoais e burocráticas, movido pelas concepções do Direito, ou seja, numa perspectiva universalista e jurídica de justiça. Nas comunidades domésticas, onde vigoram as relações baseadas no amor e na amizade, a reciprocidade é de natureza restrita ou generalizada, mas sempre dentro dos limites exclusivistas da comunidade de laços primários, envolvendo pessoas que se conhecem entre si e têm muitos laços de longa duração, excluindo as demais. Nas comunidades tais como famílias, aldeias, vizinhanças antigas etc., por definição, vigoram inúmeras perspectivas particulares e locais (não jurídicas) de justiça. Neste setor, o que está em pauta é aquilo que um outro autor denominou "valor de ligação" (Caillé, 1994), o que agrega, reúne pessoas em relações duradouras.

Num quarto setor, o da reciprocidade moderna, o dom seria enfim baseado na generosidade com estranhos e advindo de um ato gratuito e livre do doador. Ele pode ser impessoal, no sentido de que o receptor talvez nunca venha a ser conhecido, mas não exclui totalmente o cálculo de um possível retorno por meio dos intermediários, que funcionam como os agentes redistribuidores. O seu modelo, inicialmente, foi o da doação de órgãos e de sangue, que é de natureza inteiramente voluntária nos países ocidentais, mas hoje não mais se limita a esses bens que, apesar de terem doação voluntária, ainda necessitam da intermediação e redistribuição pelo Estado. Hoje, outras associações voluntárias e participativas, nas quais se trocam serviços e todas as formas de comunicação que criam relações sociais entre os parceiros, além de exigirem a participação ativa ou o engajamento responsável dos envolvidos nos objetivos coletivos, aparecem como mais representativas do quarto setor. São elas, por exemplo, as organizações dos alcoólatras anônimos, dos narcóticos anônimos e outras do mesmo gênero que não podem ser confundidas com ONGs. Nesse quarto setor, não se substituiria o caráter burocrático intermediário do Estado na redistribuição dos bens por outra organização burocrática, também ela dependente de verbas para realizar o seu trabalho de redistribuição. Do mesmo modo, por causa dos efeitos de sua própria presença na dinâmica social, os critérios particulares e locais de justiça presentes no comunitarismo, do qual decorre o funcionamento do setor doméstico, passam por uma inflexão. A autonomia local, que não organiza relações entre os vários grupos ou comunidades, rompe-se para formar cadeias de solidariedade entre estranhos cujo objetivo final pode ser a distribuição de um bem escasso, baseada em critérios diversos de justiça que implicam uma discussão pública permanente nos processos de escolha dos beneficiados. 
Em virtude disso, muitos autores que participam do debate sobre a teoria da justiça falam de um "pluralismo controlado" (conseqüência dos diferentes critérios comunitários), o qual dependeria da discussão pública dos critérios de distribuição e das avaliações a que são submetidos os que participam desses circuitos de solidariedade (Ricoeur, 1995; Boltanski, 1990; Rosanvallon, 1995). O efeito também é criar vários tipos de ligações, seja pela doação do bem, seja pela participação na discussão pública sobre a avaliação e a distribuição desse bem. Nesse circuito de reciprocidade estariam incluídos, portanto, tanto os bens mercantis quanto os não mercantis, como nacionalidade, seguridade, educação, Sistema de Justiça, ou seja, de diferentes esferas de justiça controladas pelo Estado (Walzer, 1995), ou ainda aqueles decorrentes do próprio processo de justificação das demandas por justiça e de avaliação desta, na qual as noções de honra, confiança e reputação, bens imateriais e não controlados pelo Estado, são invocadas nas disputas (Thévenot, 1995; Boltanski, 1990). Também por isso, esses autores afirmam que, quando se trata da inclusão ou da participação, não se discute mais a alocação de bens, mas, respectivamente, o controle (limitado) exercido pelo Estado em cada esfera e nas interações entre elas, ou a própria relação social. Do mesmo modo, Rosanvallon, Walzer, Ricoeur e outros sugerem a substituição de uma visão estritamente jurídica de igualdade e direitos, assim como de uma concepção puramente mecânica de redistribuição de bens, por uma prática argumentada e publicamente discutida das políticas sociais que mude o quadro da distribuição do poder político. Por fim, as críticas às teorias meramente distributivas e utilitaristas de justiça social desembocam na crítica à idéia do cidadão como sujeito passivo, mero receptor do que é distribuído pelas agências públicas. As teorias distributivas desconsiderariam a justiça, o respeito e a consideração que os cidadãos se devem mutuamente na "democracia da vida quotidiana" e que, obviamente, não são coisas que o governo possa distribuir (Shklar, 1995).

Nessa discussão, onde ficam as ambivalências do social? Onde ficam as paixões e emoções individuais que se misturam com os objetivos racionais na ação? As gratificações no plano do simbólico, da auto-estima, da luta pela notoriedade, da disputa na qual se liberam as agressividades, a ostentação do poder e da riqueza, ou a busca da justificação, que chamam a atenção dos pesquisadores, continuam a aparecer, porém com regras explícitas que levam ao que Norbert Elias (1993) denominou de "equilíbrio de tensões" em lutas prolongadas, porém controladas por regras convencionadas. Esse processo, tão bem estudado por ele no que se refere à difusão dos hábitos corteses por todos os habitantes de um país, acompanhada pela adoção de regras nas disputas pelo poder que substituíram o uso das armas pelo uso da palavra e do voto nos regimes parlamentares, permitiu também a institucionalização das disputas emocionantes, mais do que tudo pelo "prazer de competir", dos esportes e outras atividades competitivas reguladas. O próprio esporte evoluiu na direção do treinamento e autocontrole em lugar das regras costumeiras, pouco rígidas e frouxamente aplicadas que permitiam as explosões de emoções e de violência nos jogos da Idade Média, terminados muitas vezes com a morte dos participantes. Mas, nessa evolução, em que o papel do mediador e as regras acordadas ou convencionadas passaram a ocupar um lugar cada vez maior, a dinâmica do jogo continuou a pressupor a tensão e a cooperação, a solidariedade local e o interesse pela luta continuada em vários níveis ao mesmo tempo. Em outras palavras, as tensões do grupo e a cooperação encontraram um modo de estarem simultaneamente presentes na situação de "equilíbrio das tensões".

Algumas exclusões e alguns abalados circuitos de reciprocidade no Brasil

No Brasil, de um discurso retórico sobre a liberdade, passou-se a falar cada vez mais, porém ainda de modo vago, de sociabilidade, reciprocidade e comunicação no espaço público como manifestações ou mesmo o cerne da cidadania. De fato, as liberdades individuais, nos seus aspectos de negação do controle do Estado, são ferozmente defendidas pelos que gostariam que Estado e 
sociedade estivessem submetidos ao jogo livre do mercado, na busca infindável do lucro, e no jogo irrefreável das paixões humanas, especialmente no seu gosto ou vontade de poder. De que modo e onde essas liberdades deveriam ser limitadas, controladas ou reprimidas?

Isso nos leva à questão da criminalidade e sua vinculação retórica com a pobreza, o que monta uma armadilha para o cientista social. Justificar a criminalidade violenta de uma pequena parcela dos jovens pobres é desviar a atenção dos que deveriam estar sendo controlados: os que fazem fortuna traficando drogas e armas, por um lado, e os que desviam as verbas que deveriam ser destinadas às políticas públicas que educariam esses jovens para uma sociabilidade positiva e para os direitos positivos de participação. Ao mesmo tempo significa também negar-se a fazer a crítica desse ethos do lucro a qualquer preço que dominou esses jovens e que criou um poder baseado no medo e no terror em alguns bairros populares de várias cidades brasileiras. Amordaçados pela lei do silêncio, seduzidos pelos apelos dos justiceiros, grupos de defesa ou grupos de extermínio, muitos trabalhadores pobres, de várias afiliações religiosas e políticas, acabam por comprometer-se com políticas conservadoras, autoritárias e de violação dos direitos humanos no seu desespero de sair de uma situação que lhes parece insuportável. É preciso, pois, examinar com cuidado os padrões alterados de sociabilidade e de negociação de conflitos nesses locais onde as identidades parecem estar agora montadas rigidamente na lógica da guerra.

Por isso mesmo, parece-me perigosa a maneira de apresentar os dois lados da discussão pública sobre o problema da criminalidade, dividindo tanto a população em geral como os estudiosos entre os que advogam políticas sociais para combater a criminalidade entre jovens (concluise pobres) e os que defendem uma polícia e uma justiça mais eficazes por intermédio de reformas institucionais. Os vícios e problemas do Sistema de Justiça no Brasil não são poucos e já foram denunciados por muitos autores ligados à defesa dos direitos humanos, tais como Sérgio Adorno (1990), Paulo Sérgio Pinheiro et al.(1991), Antônio Luís Paixão (1988) e eu mesma. As políticas sociais devem ser implementadas não porque os pobres constituam um perigo permanente à segurança, não porque venham a ser as classes perigosas, mas porque um país democrático e justo não pode existir sem tais políticas. Em outras palavras, não convém esquecer que, apesar da enorme desigualdade existente neste país, são poucos os jovens pobres que enveredam pela carreira criminosa, exigindo, assim, um atendimento especial para eles que considere o contexto social mais próximo de suas ações, tenham eles maior ou menor controle sobre estas.

Isso nos leva ao ponto crucial da discussão. Não se trata de optar pelos preceitos liberais de que cada um faz escolhas independentemente de constrições sociais e de hábitos e aspirações exteriores aos indivíduos. Trata-se de tornar complexa a análise dos contextos sociais mais amplos e mais locais para entendermos os motivos pelos quais cada vez um número maior de jovens (de todos os estratos sociais) comete crimes, o que nem sempre significa a adoção de uma carreira criminosa, e por que alguns deles passam a exercer um tipo de poder militar nas comunidades onde as instituições encarregadas de manter a lei ou estão ausentes ou tornaram-se coniventes com o negócio ilegal ou são fracas; onde as organizações vicinais se desagregaram ou foram esvaziadas pela competição política entre partidos e grupos religiosos (Zaluar, 1995); onde as figuras paternas e maternas não mais oferecem modelos nem são capazes de controlar seus filhos. Quando isso acontece, desmantela-se o equilíbrio em tensão de suas redes de solidariedade e de rivalidade: jovens imaturos e extremamente bem armados imiscuem-se nas organizações vicinais recreativas ou políticas. Ignorar tal fato é fracassar em responder às indagações sobre os porquês de alguns jovens pobres praticarem crimes e outros não, assim como de sua forma de organização imitar os comandos militares, os bandos de guerreiros autônomos liderados por um chefe despótico.

$\mathrm{O}$ argumento que desenvolvi ao longo de 15 anos de pesquisas coloca a existência do crime organizado relacionado ao tráfico de drogas no centro desse furacão. Furtos e roubos são hoje internacionalmente vinculados à necessidade de pagar ao traficante, no caso de usuários, ou de adquirir o capital para manter o negócio das drogas, no 
caso de traficantes, que usam o poder militar para controlar seu exército de colaboradores e clientes. Ora, mesmo que os crimes registrados não estejam diretamente relacionados à droga, isto não quer dizer que a presença desse novo poder nos países capitalistas não esteja se exercendo até no plano do imaginário, como um modelo, um mapa simbólico. No plano mundial, o crime organizado, que tem estruturas complexas e movimenta um grande volume de dinheiro, não pode mais ser desconsiderado como uma força importante, ao lado dos Estados nacionais, igrejas, partidos políticos, empresas multinacionais etc. Em certos países, como a Itália, o crime organizado chegou mesmo a ser mais importante que o Estado nacional, a Igreja e os partidos. No Brasil, com o Sistema de Justiça ainda voltado para os crimes individuais e desaparelhado para investigar os meandros e grupos mais importantes do crime organizado, não temos idéia do impacto que ele hoje tem nas instituições e na sociedade.

Por exemplo, a interessante observação, constante em pesquisas recentes (Adorno et al., 1995), acerca da menor incidência de analfabetos na criminalidade dita jovem pode estar relacionada às exigências "técnicas" do crime organizado, como livros de contas e planos elaborados, que fazem da educação elementar um elemento importante na execução das tarefas. A política atual de guerra às drogas e repressão aos usuários, principalmente nos países em que os direitos de cidadania são precários, não livrou esses países do tráfico e não foi capaz de impedir a epidemia do HIV pelo uso de drogas injetáveis nos portos e cidades ao longo das rotas dos criminosos, nem a epidemia de mortes por homicídio entre os homens jovens das suas principais metrópoles.

Outros impactos, para os quais venho alertando desde 1986, não têm menos importância na vida social local em favelas e bairros populares do Rio de Janeiro. Refiro-me particularmente ao processo que transforma as quadrilhas organizadas num poder central nas favelas, onde seus chefes já expulsam moradores incômodos, matam rivais, alteram as redes de sociabilidade e interferem nas organizações. Daí a participar delas, impor currais eleitorais e espalhar o terror até dentro das casas dos trabalhadores é um passo. O jogo de futebol realizado de arma na mão e sem a manifestação do juiz é emblemático dessa situação. A interferência na escolha do samba para o desfile anula as regras convencionadas e os critérios de justiça anteriormente aceitos que, embora mantivessem acesas e emocionantes as disputas, não amedrontavam concorrentes nem calavam opositores. As cada vez mais contestadas eleições nas associações de moradores aceleram o seu esvaziamento e, conseqüentemente, o esvaziamento da participação pública nas discussões a respeito da alocação dos bens e serviços na localidade, na decisão dos próprios critérios e justificações a serem aceitos. Ao invés disso, aproximam-se os chefes locais da figura do xerife, como ocorre em favelas das capitais da América Central que sofreram a influência da cultura doscowboys, outlaws e sheriffs do Oeste norte-americano.

Voltemos, agora, à questão social com a qual se confunde a "exclusão". Nela, além da "revolução nas aspirações" a que se referiu Tocqueville quando descrevia a Inglaterra após a Revolução Industrial, e que hoje conhecemos como "privação relativa", não podemos desconsiderar as bruscas transformações na organização social. Sem dúvida, a rapidez das mudanças na organização familiar, nas relações sexuais, nos valores que faziam do trabalho a referência mais importante para amplas camadas da população, agora substituídos pelos valores associados ao consumo, especialmente o consumo de "estilo" mais caro e menos familiar (Sassen, 1991), provocou o que se poderia chamar de anomia social difusa. Além desta, é fato que o enraizamento do crime organizado nas instituições por meio da corrupção, o funcionamento altamente desigual de nosso sistema penal e a obsolescência de nosso código penal criaram "ilhas de impunidade", tais como concebidas por Dahrendorf (1987) para caracterizar outros países. Falar dessa confusão de valores e regras de conduta ao mesmo tempo que da fraqueza institucional não significa ignorar a pobreza. No entanto, neste novo cenário, a pobreza adquire novos significados, novos problemas e novas divisões. A privação não é apenas de bens materiais, até porque muitos deles têm mais importância simbólica de afirmação da posição hierárquica ou de uma identidade 
através do estilo - do que necessidade para a sobrevivência física. A privação material e simbólica é relativa, ou seja, advém da comparação com os mais aquinhoados, mas é também decorrente das necessidades desse novo tipo de consumo. A exclusão, que também tem de ser entendida em vários planos e processos, é simultaneamente de justiça, é institucional. Como já comprovaram estudos em países com Sistemas de Justiça bem mais igualitários do que o brasileiro, um inglês, se é homem, tem menos de 21 anos e cresceu numa área considerada de "delinqüência", terá 120 vezes mais chances de ser considerado um infrator ou criminoso do que uma inglesa de mais de 21 anos que mora num bairro de classe média (Jones, 1981). Isso equivale a dizer que os pobres estariam muito mais no fim do fluxo da criminalidade do que no seu início, ao menos como promotores da dinâmica inicial desta.

A corrupção policial encontrou o seu álibi no mesmo dogma da pobreza ou exclusão que tudo explica: o problema seria unicamente "social" (leia-se material). Isto garantiu a impunidade dos responsáveis por atividades ilegais e discriminatórias contra os jovens, especialmente os mais pobres, que o poder público deveria defender, tratando-os em centros de saúde e educando-os preventivamente nas escolas. Extorquidos e criminalizados pelo uso de drogas, eles acabam nas mãos de traficantes e assaltantes, ou são vítimas de chacinas que, quando esclarecidas, exibem seus reais motivos: a cobrança de dívidas ou a divisão dos lucros com policiais corruptos. Mais do que os grupos de extermínio, são os grupos de extorsão que criam o ambiente em que quadrilhas e grupos ainda mais organizados lutam pelo domínio de territórios. A tendência que São Paulo e Porto Alegre revelavam no final dos anos 80 (especialmente a primeira, onde a taxa de homicídios duplicou e segue crescendo) indica que o tráfico de drogas também está modificando o panorama da segurança pública nessas metrópoles. A pergunta que se coloca é se, lado a lado aos canais de comunicação de massa cada vez mais rápida e mais fácil devido ao processo de globalização da cultura, os policiais corruptos e violentos que usam suas armas com pouquíssimos controles institucionais não criam nos jovens pobres o fascínio pelo poder militar de tal modo exercido.

A presença de quadrilhas armadas e as guerras entre elas acrescentaram, assim, mais uma dificuldade ao ser pobre. Mesmo aceitando o reparo de que nem todos os bandos ou turmas de jovens estão vinculados à ação criminosa no Brasil, a presença cada vez maior de quadrilhas de traficantes e assaltantes é uma realidade inegável hoje em nossos centros urbanos. No Rio de Janeiro, as mortes cada vez mais prematuras, as lideranças imaturas refeitas em curto espaço de tempo, são importantes elos na cadeia de efeitos que redunda na alta taxa de mortes violentas entre jovens. Assim sendo, seria um terrível engano argumentar que, porque nem sempre o crime é uma escolha pessoal, não há separação ou diferença entre os pobres em relação às carreiras criminosas. O que importa é entender os diferentes processos, e as interações de seus efeitos, que provocam as seguidas rupturas desses jovens não com a lei, mas com as formas diversas de sociabilidade sociável, nas quais a desconfiança mútua e a hostilidade resultam na destruição mútua deles.

Do mesmo modo, reduzir os problemas e dilemas dos processos sociais complexos que articulam o local, o nacional e o global à fragmentação do social, na qual os adolescentes pobres deixam de ter alternativas futuras que não as drogas, a delinqüência ou a morte prematura, é também deixar de lado outras cadeias de efeitos igualmente importantes. Assim, acenar apenas para a escolarização, a profissionalização e para oportunidades adequadas no mercado de trabalho é simplificar a questão das drogas, usadas também por grupos profissionais bem-remunerados e prestigiados, como jornalistas e operadores da bolsa de valores, ou por estudantes universitários de famílias prósperas. A grande diferença, e aqui está outra manifestação da desigualdade neste país, é que os usuários pobres não têm o mesmo acesso a serviços de saúde para tratá-los no caso de abuso, nem para defendê-los no caso de problemas com a Justiça. Em suma, sem uma política pública que modifique a atual criminação do uso de drogas, sem uma política de redução do risco do seu uso na área da saúde e sem um projeto educativo de prevenção de seu uso 
entre os jovens não conseguiremos modificar o atual cenário de violência e injustiça existente no país.

Caso não consideremos apenas o interesse material, a renda auferida e a retórica perigosa, somos obrigados a reconhecer as conseqüências desastrosas para esse mesmo jovem pobre que se pretende defender: a guerra entre as quadrilhas já matou e vai continuar matando milhares deles, seduzidos pelo poder que a posse da arma de fogo e o pertencimento a uma quadrilha bem armada parecem inicialmente trazer. São principalmente os homens jovens pobres, negros, pardos e brancos, que estão deixando suas vidas, seja nas mãos de policiais violentos, seja nas mãos de seus colegas ou comparsas. O uso político dessa desgraça, que acrescenta ainda mais sofrimento para as famílias pobres, pode estar garantindo espaço nos jornais, mas não nos está tornando mais capazes de montar políticas públicas eficazes para minorar os problemas complexos desse quebra-cabeças. Hoje temos a enfrentar, simultaneamente, uma questão social, que é também uma questão de educação e de saúde pública, articulada a uma questão jurídico-penal e policial.

O Brasil também exibe hoje sinais de intolerância religiosa que revertem os efeitos dos processos históricos que resultaram na hibridização assumida, falada, discutida das suas culturas. No plano local, essa nova tendência tem tido conseqüências inesperadas e trágicas nas famílias pobres e em suas organizações vicinais, o que, no meu entender, tem facilitado a usurpação do poder local por grupos de traficantes, a quebra dos laços sociais dentro da família e entre famílias na vizinhança, destruindo ou invertendo o sinal dos circuitos de reciprocidade: da solidariedade para a vingança, do agônico para o antagônico, da rivalidade expressa nos variados jogos esportivos e culturais para a rivalidade mortal.

É inegável o desinvestimento nas tradições brasileiras, especialmente as criadas no Rio de Janeiro, que passaram a ter a marca do inautêntico, do politicamente manipulado para fins políticos de construir a nação brasileira. Ora, qualquer tradição cultural é, como sabemos, artificial, fruto de montagens articuladas com a política, que servem de substrato ou reforço para identidades em confronto. Mas, fora do esquema dos sinais diacríticos da diferença ou do artificialismo político das identidades, restam os laços sociais, as redes de solidariedade tecidas no dia-a-dia de suas organizações. A comunidade de sentidos é também a comunidade de trocas baseadas no princípio da reciprocidade, fora da lógica do mercado, que Habermas chamou de "mundo da vida".

Os trabalhadores pobres que conviveram em organizações vicinais, casando-se para formar famílias sem importar a raça ou o credo, assistem agora o esfacelamento das suas famílias e dessas organizações, tão importantes na criação de cultura, na conquista de uma autonomia moral e política, na participação em uma discussão pública sobre a justiça em seus multifacetados aspectos. Na última pesquisa que fiz nas favelas do Rio de Janeiro, ouvi depoimentos de mães com lágrimas nos olhos dizendo que nasceram ali, cresceram ali, indo ao samba com toda a família reunida, mas que agora queriam ir embora de um lugar cheio de conflitos, riscos e ameaças; da mãe-de-santo que penosamente contou que teve que deixar de ir à casa de seus filhos convertidos à igreja pentecostal porque o pastor proibiu sua presença "carregada", "diabólica" na casa deles, até no aniversário dos próprios netos. E vi meninos brincando de chefe dando as ordens com a arma de brinquedo apontada para os seus teleguiados. Se não foi o efeito inicial, o abandono das organizações construídas durante décadas da história republicana (Zaluar, 1985; Carvalho, 1987) nos bairros pobres do Rio de Janeiro acrescenta — se considerarmos as análises feitas anteriormente sobre a importância, no mundo de hoje, das redes de reciprocidade e das regras convencionadas que permitem a contínua manifestação controlada das emoções na disputa - mais um combustível nessa cadeia de efeitos.

Dentro da família, as divisões e afastamentos se dão pelo pertencimento a diferentes comandos (o Vermelho, o Terceiro); por posições diferentes na trincheira da guerra, que às vezes separa polícia e bandido; mas também pela conversão às igrejas pentecostais que proíbem o contato com as outras religiões, apresentadas via Embratel como manifestações do diabo, assim como pela difusão rápida, 
pela indústria cultural, dos novos estilos de cultura jovem que fizeram dos jovens consumidores de produtos especialmente fabricados para eles, seja vestimentas, estilos musicais ou drogas ilegais. A família não vai mais junta ao samba; o funk não junta gerações diferentes no mesmo espaço; o tio traficante gostaria de expulsar da favela o sobrinho do outro comando ou da polícia ou ainda do Exército; a avó negra e mãe-de-santo não pode freqüentar a casa dos seus filhos e netos pentecostais.

As metáforas da guerra, criticadas ao mesmo tempo que reforçadas nas interpretações veiculadas na mídia, ameaçam transformar-se na lógica da guerra efetivamente seguida no cotidiano dessa população. Não é por acaso que o símbolo da identidade negra mais cultuado e sagrado hoje seja justamente a figura de Zumbi, o líder negro que se recusou a negociar, a ceder, que lutou até a morte como um bravo guerreiro. É este o modelo que se apresenta para o jovem pobre negro ou mestiço nas escolas públicas, especialmente no Rio de Janeiro. Não por acaso as favelas continuam sendo identificadas com os quilombos e seus defensores como quilombolas, apesar da sua heterogeneidade interna, apesar de hoje abrigarem mais nordestinos e mineiros, sem nenhuma uniformidade racial, do que negros. Não por acaso, ali também se continua a apresentar os jovens que servem de mão-de-obra barata e bucha de canhão do crime organizado como heróicos revoltados contra a iniqüidade da desigualdade social no Brasil e vítimas do extermínio perpetrado pela polícia, sem considerar as complexas relações do crime organizado com o mundo legal dos negócios e as instituições que deveriam combatê-lo, através das quais alguns enriquecem pela associação comercial com esses jovens pobres que acabam ou mortos ou presos.

Por isso mesmo, a cidade como espetáculo da rivalidade e encontro dos diferentes grupos que a compõem também passa por uma transformação radical. Se antes os conflitos ou competições entre bairros, vizinhanças ou grupos de diversas afiliações eram apresentados, representados e vivenciados em locais públicos que reuniam pessoas vindas de todas as partes da cidade, de todos os gêneros, de todas as idades, criando sociações (Simmel, 1983), ligações, encenações metafóricas e estéticas das suas possíveis desavenças, hoje os bailes "de clube" dificilmente conseguem reunir galeras diferentes sem a ocorrência de violentos e, às vezes, mortais embates. Não que esforços muito meritórios não tenham sido feitos para "civilizar" ou, como preferem alguns, "domesticar" esses rituais guerreiros, mas é a sua lógica mais profunda que mereceria a atenção de todos nós. Os jovens das galerasfunk desenvolvem um ethos de guerreiro em que aprender a brigar e "não dar mole" é a disposição mais importante que passam a incorporar na adolescência. E isto tem como suportes a incorporação descontrolada e acrítica do processo de globalização da cultura, ainda tão mal estudado entre nós, assim como a adoção de uma política extremamente repressiva em relação a alguns de seus efeitos, como o consumo de drogas ilegais. Sem o exame desses aspectos do problema não se montarão políticas públicas eficazes para a construção de uma sociedade mais justa e mais pacífica.

No mundo em que as guerras étnicas, agora dentro de uma mesma nação, e as guerras moleculares, dentro dos mesmos grupos, classes sociais, grupos étnicos e raciais e até das mesmas vizinhanças, predominam, parece que as teias da sociabilidade, no espaço privado, e da civilidade, no espaço público, se desmantelaram. Com tantos focos reticulares de violência, como definir o mal, e, se preferirmos a opção de Paul Ricoeur, como combater o mal? A verdade é que não temos nenhuma resposta substantivista, essencialista, de ordem geral, apesar dos esforços dos defensores dos direitos humanos. O sentido do mal cometido contra a humanidade é historicamente recente. A humanidade teria adquirido hoje valores absolutos — contra o genocídio, por exemplo - e uma Carta de Direitos Humanos, aprovada pelas Nações Unidas. Esse mal que atinge o humano, tal como no genocídio ou nos atentados aos direitos humanos, é uma concepção moderna e tem apenas duzentos anos dentro da tradição ocidental iluminista (Ricoeur, 1986).

O problema é que, na violência molecular, mesmo que cada vez menos privada, esses termos gerais dos direitos humanos não se aplicam com facilidade. Ao contrário, criam enormes dissensões entre os que são alvo do terror e sentem medo e os que se fascinam pelo poder assim 
adquirido. Desse modo, tornou-se necessário analisar cada caso no seu contexto, cada contexto nos seus múltiplos aspectos, cada aspecto no seu processo específico, e teremos não dois campos opostos de luta, mas uma luta diversificada em várias frentes. Sem cair nas armadilhas do relativismo, praticando porém a relativização, teremos de analisar as conseqüências dos atos violentos para a pessoa ou grupo que os pratica, assim como os efeitos de seus atos sobre terceiros, meros passantes, espectadores, vítimas inocentes, parte da luta pela sobrevivência posta na disputa por territórios urbanos, parte das rivalidades em torno das quais se movem homens orgulhosos em busca de poder e prestígio.

As mesmas pessoas que falam tanto da globalização da economia insistem em repetir uma fórmula usada para criticar a política de segurança da República Velha — a questão social não é questão policial —, quando a criminalidade no Brasil tinha características muito diversas das encontradas hoje nas cidades do país, negando-se a perceber o fenômeno da globalização do crime. Naquela época, eram os acusados de vadios e desordeiros que enchiam as prisões do país. Hoje são os criminosos pobres envolvidos nas malhas do tráfico de drogas, assaltando e roubando para pagar suas dívidas com os traficantes, adquirindo capital através de seqüestros para se estabelecer no negócio, ou iniciando sua carreira com a condenação de pena privativa de liberdade por causa de um cigarro de maconha.

Não há como negar a necessidade de se entender essa onda recente de violência não apenas como efeito geológico das camadas culturais da violência costumeira no Brasil, mas também dentro do panorama do crime organizado internacionalmente, do crime também ele globalizado, com características econômicas, políticas e culturais sui generis, sem perder algo do velho capitalismo da busca desenfreada do lucro a qualquer preço. A necessidade de estender a análise para fora das fronteiras nacionais, no caso do estudo da sociedade criminosa, ou seja, daqueles que optam por viver nem sempre como fora-da-lei, mas numa mistura peculiar de negócios legais e ilegais, não pode ser negada diante das evidências. A imagem do menino favelado com um fuzil AR15 ou uma metralhadora UZI na mão, as quais considera como símbolos de sua virilidade e fonte de grande poder local, com um boné inspirado no movimento negro da América do Norte, ouvindo música funk, cheirando cocaína produzida na Colômbia, ansiando por um tênis Nike do último tipo e um carro do ano não pode ser explicada, para simplificar a questão, pelo nível do salário mínimo ou pelo desemprego crescente no Brasil, tampouco pela violência costumeira do sertão nordestino. Quem levou até ele esses instrumentos do seu poder e prazer, por um lado, e quem e como se estabeleceram e continuam sendo reforçados nele os valores que o impulsionam à ação na busca irrefreável do prazer e do poder, por outro, são obviamente questões que independem do salário mínimo local.

Faz parte desse contexto social, portanto, a facilidade de se obter armas nos Estados Unidos e a política de guerra às drogas que se mostrou ineficiente e cara para diminuir o consumo, mas extremamente eficaz em aumentar o nível de violência entre os negros, assim como as idéias correntes que inspiram as políticas de segurança daquele país. É o alto nível de homicídios entre os negros que leva observadores conservadores a afirmar que não existe um problema criminal nos Estados Unidos, mas um problema negro de crime, nessa peculiar visão segregada da sociedade americana, ou, pior ainda, que os políticos conservadores devem lavar as mãos com a consciência tranqüila, pois a responsabilidade pela matança é exclusivamente dos negros.

Tais afirmações, como fica claro para qualquer leitor medianamente atento, não implicam uma postura contra o aumento do salário mínimo nem contra a distribuição de renda no país, que apresenta um dos índices mais altos, senão o maior, de desigualdade social no mundo, mas sim um alerta para o fato de que apenas o aumento do salário mínimo ou a implementação de políticas públicas que não contemplem a especificidade da nova criminalidade não serão suficientes nem eficazes. Até porque frisar os altos ganhos daquilo que os favelados chamam "dinheiro fácil" é decretar o fracasso de qualquer política social, pois são raríssimos os empregos, mesmo os de classe média, que 
oferecem os níveis de renda supostamente existentes no tráfico de drogas ilegais. Ao mesmo tempo, é preciso desenvolver instrumentos teóricos para entender essa mortandade, esse antagonismo violento que desconhece as regras da sociabilidade, do respeito mútuo, da aceitação do outro, e que classifica qualquer mínima diferença de local de moradia, turma, galera, de algumas das festejadas tribos urbanas que redefiniram identidades sociais em termos territoriais como sinal de inimigo mortal, do "alemão" que pode ou deve ser morto, numa óbvia imitação, mesmo que incompleta, das gangs que existem nos Estados Unidos desde o começo do século (Zaluar, 1997a e 1997b).

Uma tarefa de tal monta, que envolve tantos e tão complexos processos, não pode ser exclusividade de nenhuma instância ou organização (governamental ou não). Estes problemas tampouco serão resolvidos com o funcionamento focalizado do Sistema de Justiça, que pune o criminoso menor, menos importante no circuito dos envolvidos e menos responsável, por assim dizer, pelo início do fluxo das atividades criminosas, especialmente as relacionadas com o tráfico (Zaluar, 1997c). Também não serão resolvidos apenas com políticas de emprego ou com o aumento do salário, inclusive dos funcionários públicos, entre eles os policiais, os mais ativos hoje no movimento sindical.

Alternativas de emprego para os jovens não devem faltar, mas é preciso sobretudo restaurar as redes locais de reciprocidade positiva, reforçar as solidariedades enfraquecidas entre as gerações, intra e extra-classe, assim como, nas políticas públicas, abrir espaço político para reconhecer e estabelecer parcerias com todas as formas de associações que promovem aquelas reciprocidades e solidariedades, principalmente no quarto setor. Isto também significa estar atento e responder às insidiosas tendências da globalização via mídia e indústria cultural, principalmente aquelas que alteraram as formas de sociabilidade e de solidariedade mencionadas acima, sobretudo as que organizam os jovens das camadas mais pobres. Por isso, é preciso um trabalho intenso com a juventude para reconquistar seus corações e mentes, com a valorização daquilo que foi montado no país pela iniciativa política e a criatividade cultural das camadas da população chamadas de populares, subalternas, trabalhadoras ou dominadas.

Refeitas as redes de solidariedade e dadas as condições para que a sociabilidade volte a manter viva as sociedades locais e mobilizados os jogos sociais, é possível pensar em deixálas escolher localmente (e não nomear pelo governo) a composição dos comitês e comissões que se multiplicaram pelo país afora, tornando-as mais legítimas. No funcionamento precário desta democracia que pretende ir além dos limites da democracia eleitoral ou representativa, os problemas enfrentados nesses comitês têm minado a tentativa de adjetivar de participativos os novos procedimentos democráticos, tais como o orçamento participativo de prefeituras, os comitês da Comunidade Solidária etc. Last but not the least, políticas de segurança pública democráticas trarão de volta a efervescência social e cultural que os trabalhadores (dos setores formal e informal da economia) perderam com a crescente violência entre seus vizinhos e a polícia, especialmente a militar. Isso já aconteceu em várias favelas e conjuntos habitacionais do Rio de Janeiro durante o curto policiamento a eles oferecido pela Polícia Civil com base em novas regras de respeito aos moradores. Nesta ocasião, as ruas e vielas encheram-se novamente de crianças jogando bola, de adultos em torno de mesas postas na rua para jogos variados (Alvito, 1997) e conversas cuja única finalidade era desenvolver o prazer de conversar, além das comemorações e festas que sempre ofereceram as oportunidades para ativar e acelerar os inúmeros circuitos de reciprocidade com os quais os moradores refazem a eternamente buscada união, garantia contra a atomização, o individualismo negativo e a fragmentação do social que tanto preocupam os que estudam as sociedades póstradicionais e pós-industriais. 


\section{NOTAS}

1 O debate entre universalistas e comunitaristas movimentou muito mais o meio acadêmico da América do Norte e não será objeto de discussão aqui. O livro Liberals and communitarians (Mulhall e Swift, 1992) apresenta ao leitor interessado uma parte desse debate, centrado na obra de J. Rawls. Os autores aqui discutidos rompem mais claramente com os pressupostos do individualismo associal ou mesmo com a idéia de contrato entre indivíduos livres e iguais, base do contrato civil, criticados nos universalistas norteamericanos.

2 No folclore brasileiro, a expressão "ou humilha o homem ou vicia o cidadão" para referir-se à esmola é a mais perfeita tradução do que queria dizer Mauss a respeito do dom não retribuído.

3 Em algumas favelas do Rio de Janeiro, calcula-se que 30\% da população original já tenha deixado o local por causa da violência. Cf. O Globo, 23/5/96.

4 No Rio de Janeiro, hoje, há dois tipos de bailes funk: os "de comunidade", aos quais só comparecem jovens daquele bairro ou favela e onde não há conflitos, e os "de clube", nos quais se reúnem jovens de diferentes locais com o objetivo de se enfrentarem ritualmente dentro do baile e fora dele, após o seu término (Cecchetto, 1997).

\section{BIBLIOGRAFIA}

ADORNO, Sérgio. (1990), Violência urbana, justiça criminal e organização social do crime. São Paulo, Núcleo de Estudos da Violência da USP, mimeo.

ADORNO, S.; BIDERMAN, F.; FEIGUIN, D. e LIMA, R.S. (1995), O jovem e a criminalidade urbana de São Paulo.São Paulo, Fundação SEADE/Núcleo de Estudos da Violência da USP.
AFFICHARD, Joëlle. (1995), "Du débat sur les inegalités au pluralisme contrôlé", in J. Affichard e J.B. Foucauld,Pluralisme et equité, Paris, Commissariat Général du Plan, Éditions Esprit.

ALVITO, Marcos. (1997), "Notas sobre um bicho de sete cabeças", in A. Zaluar e M. Alvito, Cem anos de favela, no prelo.

BOILLEAU, Jean-Luc. (1995), Conflit et lien social: la rivalité contre la domination. Paris, Ed. La Decouverte/ M.A.U.S.S.

BOLTANSKI, Luc. (1990), L'amour et la justice comme compétences; trois essais de sociologie de l'action. Paris, Éditions Métailié

CAILLÉ, Alain. (1994), Don, intérêt et désintéressement; Bourdieu, Mauss, Platon et quelques autres. Paris, Éditions La Découverte/ M.A.U.S.S.

CARVALHO, José Murilo de. (1987), Os bestializados; o Rio de Janeiro e a República que não foi. São Paulo, Companhia das Letras.

CASTEL, Robert. (1995), Les métamorphoses de la question sociale; une chronique du salariat. Paris, Librairie A. Fayard.

CASTELS, Manuel e MOLLENKOPF, John (eds.). (1992), Dual city: restructuring New York. Nova Iorque, Russel Sage Foundation.

CECCHETTO, Fátima. (1997), "Galeras funk cariocas: entre o lúdico e o violento", in H. Vianna, Galeras cariocas, Rio de Janeiro, Editora da UFRJ.

DAHRENDORF, Ralph. (1987), A lei e a ordem. Brasília, Instituto Tancredo Neves.

DANZINGER, Sheldom e WEINBERB, Daniel (eds.). (1986),Fighting poverty. Boston, Harvard University Press. 
ELIAS, Norbert. (1993), "Introduction", in N. Elias e E. Dunning, Quest for excitement, sport and leisure in the civilizing process. 1ª edição paperback, Oxford, Blackwell.

FARRUGIA, Francis. (1993), La crise du lien social. Paris, Éditions L'Harmattan, Collection Logiques Sociales.

GODBOUT, Jacques T. (1992), L'esprit du don. Paris, Éditions la Découverte.

HABERMAS, Jürgen. (1991), Pensamento pós-metafísico. Rio de Janeiro, Tempo Brasileiro.

HIMMELFARB, Gertrud. (1984), The idea of poverty.Londres, Faber and Faber.

JENKS, Christopher. (1992), "The ghetto" e "The underclass", in C. Jenks, Rethinking social policy, Boston, Harvard University Press.

JONES, Howard. (1981), "Punishment or correction?", in H. Jones, Society against crime, Middlesex/Nova Iorque, Penguin Books.

KATZ, Michael. (1989), "Interpretations of poverty in post-industrial cities" e "The underclass?", in M. Katz, The undeserving poor, Nova Iorque, Pantheon Books.

MULHALL, Stephan e SWIFT, Adam (eds.). (1992), Liberals and communitarians. Oxford, Blackwell.

PAIXÃO, Antonio L. (1988), "Crime, controle social e consolidação da cidadania", in F.W.Reis e G.O'Donnell, $A$ democracia no Brasil: dilemas e perspectivas, São Paulo, Vértice.

PINHEIRO, Paulo S. et al. (1991), "Violência fatal: conflitos policiais em São Paulo (81-89)". Revista da USP, 95.

RICOEUR, Paul. (1986), O mal. Campinas, Papirus. (1990), Soi-même comme un autre. Paris, Le

Seuil.
(1995), "La place du politique dans une conception pluraliste des principes du juste", in J.Affichard e J.B.Foucauld, Pluralisme et equité, Paris, Commissariat Général du Plan, Éditions Esprit.

ROSANVALLON, Pierre. (1995), La nouvelle question sociale. Paris, Editions du Seuil.

SASSEN, Saskia. (1991), The global city: New York, London, Tokyo. Princeton, Princeton University Press.

SHKLAR, Judith. (1995), "Justice et citoyenneté", inJ.Affichard e J.B.Foucauld, Pluralisme et equité, Paris, Commissariat Général du Plan, Éditions Esprit.

SIMMEL, Georg. (1983), "A natureza sociológica do conflito", "A competição", "Sociabilidade, um exemplo de sociologia pura ou formal", in Simmel, São Paulo, Ática.

TAMBIAH, Stanley J. (1997), "Conflito etnonacionalista e violência coletiva no sul da Ásia". Revista Brasileira de Ciências Sociais, 12, 34: 5-24.

THÉVENOT, Laurent. (1995), "L'action publique contre l'exclusion dans des approches pluralistes du juste", inJ.Affichard e J.B.Foucauld, Pluralisme et equité, Paris, Commissariat Général du Plan, Éditions Esprit.

WALZER, Michael. (1995), "Exclusion, injustice et État démocratique", in J. Affichard e J.B.Foucauld, Pluralisme et equité, Paris, Commissariat Général du Plan, Éditions Esprit.

ZALUAR, Alba. (1985), A máquina e a revolta. São Paulo, Brasiliense.

(1995), "O medo e os movimentos sociais". Revista Proposta, ano 23, 66: 24-32. .(1997a), "Gangs, galeras e quadrilhas: globalização, juventude e violência", in H. Vianna, Galeras cariocas, Rio de Janeiro, Editora da UFRJ. 
(1997b), "As imagens da e na cidade: a superação da obscuridade". Cadernos de Antropologia e Imagem, 3,2 .

(1997c), Justiça, violência e dinheiro fácil.

Trabalho apresentado no Institut des Hautes Études sur la Justice, Paris, mimeo, março. 